\title{
ROLE OF DIET-RELATED FACTORS IN CEREBRAL ANEURYSM FORMATION AND RUPTURE
}

\author{
Anna Czekajtol \\ ${ }^{1}$ Department of Dietetics, Wroclaw Medical University, Faculty of Health Sciences, Wroclaw, Poland
}

\begin{abstract}
Cerebral aneurysms (CAs) are dilations of the wall of an artery in the brain filled with blood. The prevalence of unrupted CA in general population is estimated at approximately $3 \%$. Ruptured aneurysms are the cause of $85 \%$ of spontaneous subarachnoid hemorrhage (SAH) cases. The formation of cerebral aneurysms results from various factors, including chronic inflammation, hemodynamic stress and vascular wall remodeling. Reactive oxygen species may induce the endothelial dysfunction possibly through the activation of Nuclear Factor Kappa-B, which is a key regulator of the proinflammatory genes. Hypertension may additionally increase the hemodynamic stress and activate the local renin-angiotensin system. The aim of this review was to assess the role of selected diet-related factors in the formation and rupture of cerebral aneurysms. It appears that inadequate intake of dietary antioxidants, hyperhomocysteinemia, hypertension (including incidental elevated blood pressure) and alcohol consumption may increase the risk of intracranial aneurysms. Individuals at high risk of $\mathrm{CA}$ formation and/or rupture should consume adequate amounts of antioxidant vitamins (vitamin $\mathrm{C}$, vitamin $\mathrm{E}$ and carotenoids), $\mathrm{B}$ vitamins (vitamin $\mathrm{B}_{6}$, vitamin $\mathrm{B}_{12}$ and folate), flavonoids and $\mathrm{n}-3$ fatty acids, limit alcohol and caffeine consumption and regularly control their blood pressure. Vegetables, fruits, grains, pulses, nuts and fish, as well as herbs, spices and tea, should be the major components of the daily diet. Due to the synergistic effect of various dietary components on health, Mediterranean diet or Dietary Approach to Stop Hypertension (DASH) diet, as they meet abovementioned requirements and have high anti-inflammatory potential, are thus recommended for the prevention of cerebral aneurysm formation and rupture.
\end{abstract}

Key words: cerebral aneurysm, diet, antioxidant intake, hypertension, hyperhomocysteinemia, alcohol consumption

\section{STRESZCZENIE}

Tętniaki mózgu to ograniczone poszerzenia światła naczynia krwionośnego wypełnione krwią. Występowanie tętniaków mózgu w ogólnej populacji wynosi około 3\%, a pęknięcie tętniaka jest przyczyną 85\% przypadków krwotoku do przestrzeni podpajęczynówkowej. Na powstanie tętniaka mózgu wpływa wiele czynników, w tym przewlekły stan zapalny, stres hemodynamiczny i przebudowa ścian naczyń mózgowych. Reaktywne formy tlenu mogą nasilać dysfunkcję śródbłonka m.in. poprzez aktywację jądrowego czynnika transkrypcyjnego NF-kB, który jest głównym regulatorem genów związanych z przebiegiem procesu zapalnego. Ponadto wysokie ciśnienie tętnicze krwi może nasilać stres hemodynamiczny oraz aktywować lokalny układ renina-angiotensyna-aldosteron. Celem artykułu był przegląd piśmiennictwa dotyczącego roli wybranych czynników związanych z dietą i z ryzykiem powstania i pęknięcia tętniaków mózgu. Wydaje się, że niewystarczająca podaż składników o działaniu antyoksydacyjnym, hiperhomocysteinemia, nadciśnienie tętnicze (w tym nagłe skoki ciśnienia tętniczego krwi) oraz spożycie alkoholu mogą zwiększać ryzyko rozwoju tętniaków mózgu. Osoby o podwyższonym ryzyku powstania i/lub pęknięcia tętniaka mózgu powinny więc stosować dietę o odpowiedniej zawartości witamin antyoksydacyjnych (witamina $\mathrm{C}$, wit. $\mathrm{E}$ i $\beta$-karotenu), witamin $\mathrm{z}$ grupy $\mathrm{B}$ (witamina $\mathrm{B}_{6}$, witamina $\mathrm{B}_{12}$ i foliany), flawonoidów i kwasów tłuszczowych z rodziny n-3, ograniczyć spożycie alkoholu i kofeiny, a także regularnie monitorować wartości ciśnienia tętniczego krwi. Stosowana dieta powinna być bogata w warzywa, owoce, produkty zbożowe, nasiona roślin strączkowych, orzechy i ryby, jak również przyprawy, zioła i herbatę. Ze względu na synergistyczny efekt działania różnych składników diety na zdrowie, w prewencji tętniaków mózgu rekomendowane powinny być diety: śródziemnomorska i DASH, charakteryzujące się odpowiednią zawartością wymienionych składników oraz wysokim potencjałem antyoksydacyjnym.

Słowa kluczowe: tętniaki mózgu, dieta, podaż antyoksydantów, nadciśnienie tętnicze, hiperhomocysteinemia, spożycie alkoholu

Corresponding author: Anna Czekajło, Department of Dietetics, Wroclaw Medical University, Parkowa str. 34, 51-616 Wroclaw, Poland, e-mail: anna.czekajlo@umed.wroc.pl

CC Copyright by the National Institute of Public Health - National Institute of Hygiene 


\section{INTRODUCTION}

Cerebral aneurysms (CAs) are defined as dilations of the wall of an artery in the brain filled with blood. The worldwide prevalence of unrupted CA is estimated at approximately 3\% [47]. Brain aneurysm may remain asymptomatic, cause non-specific neurological symptoms (as change in vision or dilated pupil), leak or rupture. The symptoms of a ruptured cerebral aneurysm usually include severe headache, nausea and vomiting, stiff neck, seizure and loss of consciousness [11]. Ruptured aneurysms are the cause of $85 \%$ of spontaneous subarachnoid hemorrhage (SAH) and are fatal in about $40 \%$ of cases. The annual rate of SAH is approximately 6-16 per 100000 people [55].

CAs are usually diagnosed using an magnetic resonance imaging (MRI) or a computerized tomography (CT) scan. The incidence of SAH is higher in women than in men and increases with age. Medical factors associated with the incidence of unrupted CAs are: family history of aneurysm or SAH, autosomal dominant polycystic kidney disease, connective tissue disorders, intracranial arteriovenous malformation and coarctation of the aorta. Common modifiable risk factors include also cigarette smoking, hypertension, drug abuse and heavy alcohol consumption [21, 47]. Diet is rarely mentioned as a direct risk factor for CA formation or rupture, however it indirectly participates in the pathogenesis of CAs but also may affect other risk factors.

The aim of this review was to assess the role of dietary intake and selected diet-related factors in the formation and rupture of cerebral aneurysms.

\section{PATHOPHYSIOLOGY OF CEREBRAL ANEURYSMS}

The formation of cerebral aneurysms results from the multifactorial mechanisms, however it is believed that the key factor that determines the development of this process on a structural level is a defect of the cerebral arteries. The weakening of the wall of an artery may cause the disruption of the internal elastic lamina. Moreover, the reconstitution of the collagen fiber results in the additional collagen and elastin degradation which leads to the artery wall remodeling. All these processes may cause the inner membrane to bulge and form aneurysms [13]. Recently, several genes and genetic loci were found to be related to the development of cerebral aneurysms but obtained results seems to be rather group-specific due to the strong population heterogeneity [46]. Nonetheless, the prevalence of unrupted CAs appears to be significantly higher among the first-degree relatives of those affected with brain aneurysms (19.1\%) compared with the general population (2-3\%) [7].
Structural remodeling of the cerebral arteries may be modulated by hemodynamic and oxidative stress. High levels of free radicals, mainly superoxide $\left(\mathrm{O}_{2} \bullet\right)$ and hydrogen peroxide $\left(\mathrm{H}_{2} \mathrm{O}_{2}\right)$, induce chronic inflammation and cell injury. The possible sources of free radicals in cerebral arteries are vascular nicotinamide adenine dinucleotide phosphate oxidase (NADPH), hemeoxygenase-1 (HO-1) and inducible nitric oxide synthase (iNOS). Aoki et al. [3] observed that reactive oxygen species (ROS) were overproduced in the aneurysmal walls, while the deletion of the ROSproducing gene, $\mathrm{p} 47 \mathrm{phox}$, inhibited CAs formation and decreased inflammation level in aneurysmal walls.

ROS may affect the endothelial dysfunction primarily through the activation of Nuclear Factor Kappa-B (NF- $\mathrm{kB}$ ) which is a key regulator of the proinflammatory genes, including vascular cell adhesion molecule-1 (VCAM-1) and monocyte chemoattractant protein-1 (MCP-1). MCP-1 induces macrophage recruitment and its inactivation was shown to inhibit CAs formation in animal models [1]. Endothelial dysfunction is followed by smooth muscle cell phenotypic modulation and eventually cell apoptosis. It appears that the level of macrophage infiltration and smooth muscle cells proliferation is associated with the risk of aneurysm rupture [14].

Inflammation may be exerted by coexisting hypertension, which increases hemodynamic stress and activates the local renin-angiotensin system (RAS). RAS can control vascular remodeling not only through smooth muscle cell migration and proliferation, but also by the activation of NF- $\mathrm{BB}[25$, 43]. All the above-mentioned mechanisms may be also intensified by cigarette smoking which is considered as an independent but modifiable risk factor for cerebral aneurysm formation and rupture. Woo et al. [50] observed that the odds ratio for aneurysmal subarachnoid hemorrhage in group of current smokers without family history of SAH was 3.1 (95\% CI 2.2-4.4) compared to current nonsmokers. Smoking may increase wall shear stress, cause endothelial dysfunction and smooth cell proliferation and intensify inflammatory response through various mechanisms, including extracellular signal-regulated protein kinase 1 and $2($ ERK1/2) and NF-kB pathways [10].

\section{DIET-RELATED RISK FACTORS FOR CEREBRAL ANEURYSM FORMATION AND RUPTURE}

\section{Antioxidant intake}

As oxidative stress and inflammation play a key role in cerebral aneurysms formation and rupture, therapies focused on the inhibition of inflammatory cascade may provide a beneficial effect on CAs prevention 
and treatment. In animal models, anti-inflammatory agents, such as tolylsam (metalloproteinase-2, -9 and -12 inhibitor), edaravone (free radical scavenger) and celecoxib (cyclooxygenase-2 (COX-2) inhibitor), decreased the size and the incidence of advanced CAs [2-4]. Hasan et al. [17] observed that the risk of subarachnoid hemorrhage was lower in patients with unrupted CAs who used aspirin, which is known as a COX-2 inhibitor, compared with those who never used acetylic acid.

Dietary components with antioxidant activity include carotenoids, vitamin $\mathrm{C}$, vitamin $\mathrm{E}$ and flavonoids. In various studies antioxidant intake was inversely associated with the risk of cardiovascular disease, coronary heart disease, stroke and cardiovascular/total mortality $[5,9,20]$. The cumulative effect of dietary antioxidants may be illustrated by total antioxidant capacity (TAC) index which is also considered as an indicator of the quality of the diet [32]. Rautiainen et al. [34] shown that total antioxidant capacity was associated with lower risk of hemorrhagic stroke among women with the history of cardiovascular diseases (the hazard ratio for the highest vs. lowest quartile of TAC $0.55 ; 95 \%$ CI $0.32-0.95$; $p$ for trend 0.03). In a study performed by Colarusso et al. [12] women in the highest quartile of antioxidant capacity had a $27 \%$ lower HR of total stroke in comparison with women in the lowest quartile $(95 \%$ CI 0.53-0.99; $\mathrm{p}$ for trend 0.03).

Marzatico et al. [24] showed that systemic plasmatic levels of vitamin A and vitamin $\mathrm{E}$ were lower in patients suffering from SAH compared with controls with unrupted CA ( $\mathrm{p}=0.038$ and 0.0158 , respectively), while the activity of A1AT, an enzyme inhibitor that protects the tissues from inflammatory damage, was reduced in group of patients with SAH $(\mathrm{p}=0.019)$. According to authors, reduced antioxidant status and consequent oxidative stress might increase the sensibility of alpha1-antitrypsin (A1AT) to oxidative reactions and influence the rupture of brain aneurysms. In a study performed by Gopal et al. [16] the injection of angiotensin II, a regulatory peptide involved in maintaining homeostasis of cardiovascular system, induced cerebral aneurysm formation in ApoE -/- mice by modulating the mRNA levels of matric metalloproteinases (MMPs), plasminogen activators and adhesion molecules. $\beta$-carotene supplementation regulated the expression of above-mentioned genes, reduced the circulating macrophage levels and prevented aneurysm formation.

Curcumin (diferuloylmethane) is the main curcuminoid of turmeric (Curcuma longa) having anti-inflammatory and radical scavenging properties. Antioxidant effect of curcumin may be associated with the inhibition of pro-inflammatory enzymes, including COX-2, iNOS and lipoxygenase (LOX).
Oral administration of curcumin reduced the activity of NF- $\mathrm{KB}$ and lowered aortic concentrations of proinflammatory cytokines and tissue remodeling in experimental abdominal aortic aneurysms [30]. Bo et al. [6] observed that curcumin decreased apoptosis in cerebral aneurysm-induced smooth muscle cells of male albino rats possibly through the reduction of the p53 expression.

In a case-control study performed by Okamoto et al. [26], involving 201 patients with incident SAH and 201 controls, the antioxidant intake score was associated with the reduced risk of subarachnoid hemorrhage after adjustment for confounding variables (lowest vs. highest score: OR $0.54 ; 95 \% \mathrm{CI}$ $0.30-0.99)$. An antioxidant intake score was estimated for each participant based on the data from the food frequency questionnaire (FFQ). Food products from the FFQ were grouped into five categories: green/ yellow vegetables, fruits, soy products, rice and tea. Antioxidant intake from dietary supplements was not considered in the study. Dietary pattern characterized by high intake of soy products was associated with lower risk of SAH (highest vs. lowest quartile: OR 0.46 ; 95\% CI 0.18-0.88) [27]. The highest risk for SAH was observed in group of participants who rarely consumed soy products and simultaneously smoked cigarettes (OR 5.3; 95\% CI 2.0-14.3). Less frequent intake of soy products was related to elevated risk of SAH independently of smoking habits [28]. Habitual green tea consumption was associated with decreased risk of SAH. Individuals consuming $\geq 1$ serving per day had ORs of 0.56 (95\% CI 0.32-0.98) in comparison with these who did not consume green tea ( $\mathrm{p}$ for trend $<0.001$ ) [29].

\section{Hyperhomocysteinemia}

Homocysteine (Hcy) is a sulfur amino acid biosynthesized from the essential amino acid methionine. Elevated serum Hcy level is considered an independent risk factor for cardiovascular diseases. Peng et al. [31] observed that the highest compared to lowest homocysteine level categories were associated with a $66 \%$ increased risk of coronary heart disease mortality (RR $1.66 ; 95 \%$ CI 1.12-2.47; $\mathrm{p}=0.012), 68 \%$ increased risk of cardiovascular mortality (RR 1.68; 95\% CI 1.04-2.70; $\mathrm{p}=0.033$ ) and $93 \%$ increased risk of all-cause mortality (RR 1.93; 95\% CI 1.54-2.43; $\mathrm{p}<0.001$ ). According to Wald et al. [49] the reduction of blood homocysteine level by $3 \mu \mathrm{mol} / 1$ might reduce the risk of deep vein thrombosis by $25 \%$ (8\%-38\%), stroke by $24 \%$ (15\%$33 \%)$ while ischemic heart disease by $16 \%(11 \%-20 \%)$. In a meta-analysis of seven studies performed by Zhou et al. [54] Hcy levels were significantly higher in group of patients with intracerebral hemorrhage compared to healthy controls (standard mean difference $0.59 ; 95 \%$ CI $0.51-0.68, \mathrm{p}<0.001)$. 
$X u$ et al. [52] observed that a high L-methionine diet $(1 \mathrm{~g} / \mathrm{kg} / \mathrm{d})$ was related to increased plasma homocysteine levels and accelerated cerebral aneurysm formation after ligation of the left common carotid artery in rats. Methionine treatment increased the expression of iNOS, MMP-2, MMP-9 and vascular endothelial growth factor (VEGF) in aneurysmal walls, what indicates the possible effect on vascular wall modeling in a rat model. In another study subarachnoid hemorrhage resulting from aneurysm rupture was observed more frequently in rats with methionine-induced hyperhomocysteinemia compared to controls $(\mathrm{p}<0.05)$. The level of interleukin-6 (IL-6), mRNA level of MMP-9 and the ratio of MMP-9 to the tissue inhibitor of metalloproteinase-2 (TIMP2) were also higher in group of methionine-treated rats $(\mathrm{p}<0.05)$ [22].

Hyperhomocysteinemia as a risk factor for intracranial aneurysms in human was analyzed in a casecontrol study performed in Chinese population. The serum homocysteine level was significantly higher in group of patients with intracranial aneurysms compared to aneurysm-free controls $(19.98 \pm 10.84 \mu \mathrm{mol} / \mathrm{L}$ vs. $15.13 \pm 5.55 \mu \mathrm{mol} / \mathrm{L} ; p<0.001)$. Total Hcy level $>15 \mu \mathrm{mol} / \mathrm{L}$ was associated with higher risk of CA development (adjusted OR 2.196; 95\% CI 1.188-4.057; $\mathrm{p}=0.012$ ) [36]. Nevertheless, in a study performed by Rosi et al. [37] in Brazil, median homocysteine serum level was similar in group of patients with CA in comparison with controls $(10.5 \mu \mathrm{mol} / \mathrm{L}$ [8.3-14.0] vs. $10.7 \mu \mathrm{mol} / \mathrm{L}$ [8.2-13.3]; $\quad \mathrm{p}=0.450)$. No statistically significant difference in the prevalence of hyperhomocysteinemia was observed in group of patients and controls (20.4\% vs. $7.9 \%$, respectively; $\mathrm{p}=0.073$ ).

Elevated Hcy levels may result from nutritional deficiencies of folate, vitamin $\mathrm{B}_{6}$ and $\mathrm{B}_{12}$. Although the results of studies concerning the beneficial effects of reduction of serum Hcy on cardiovascular diseases and mortality are not conclusive, it appears that adequate vitamin $\mathrm{B}$ intake may possibly protect from intracranial aneurysm formation. Ren et al. [36] observed that serum homocysteine level was negatively correlated with vitamin $\mathrm{B}_{12}$ and folate levels in group of individuals with CAs $(\mathrm{r}=-0.531 ; \mathrm{p}<0.001$ and $\mathrm{r}=$ $0.349 ; \mathrm{p}<0.001$, respectively). In a study performed by Korai et al. [22] folic acid eliminated the unfavorable effect of methionine on aneurysm growth in rats, what indicates a relationship between elevate Hcy level and CAs formation.

\section{Hypertension}

Hypertension is one of the most common risk factors for aneurysm formation and rupture. The mean incidence of pre-existing hypertension was observed in $43.5 \%$ of individuals with intracranial aneurysm compared to $24.4 \%$ in the general population [18]
In a study of Isaksen et al. [19] mean systolic blood pressure (BP) was higher in patients with aneurysmal subarachnoid hemorrhage compared to controls (154.0 $\pm 32.5 \mathrm{mmHg}$ vs. $136.3 \pm 23.3 \mathrm{mmHg}$; $\mathrm{p}=0.017)$. An increase in systolic BP of $20 \mathrm{mmHg}$ was an independent risk factor for SAH (OR 2.46; 95\% CI 1.52-3.97).

According to the Guidelines for the management of patients with unruptured intracranial aneurysms defined by the American Heart Association/American Stroke Association in 2015, individuals with unrupted CA should monitor their blood BP and undergo antihypertensive treatment [44]. In a study performed by Tada et al. [43] the normalization of blood pressure after CA formation prevented aneurysm rupture in mice and the effect was dose-dependent. The use of anti-hypertensive agents reduced the risk not only by decreasing BP but also by inhibiting the activity of the local RAS system.

The modifiable risk factor for incidental high blood pressure is caffeine intake. Isaksen et al. [19] observed that drinking more than five cups of coffee per day was more common among patients with $\mathrm{SAH}$ compared to controls $(85 \%$ vs. $59 \%, \mathrm{p}=0.004)$ and was an independent risk factor for SAH (OR 3.86; 95\% CI 1.01-14.73). In a study performed by Vlak et al. [48] coffee consumption was a trigger risk factor for aneurysm rupture (RR 1.7; 95\% CI 1.2-2.4). Similar relationship was observed with reference to cola consumption (RR 3.4; 95\% CI 1.5-7.9). Coffee consumption accounted for $10.6 \%$ of the cases of CA rupture.

There is no evidence based on clinical trials indicating that lowering BP may be used in the primary prevention of aneurysm formation. Nonetheless, it appears that maintaining normal blood pressure might have beneficial effect in individuals who are at high risk of CA formation due to family history. As nutritional factors are associated with the risk of hypertension, dietary modifications, e.g. Mediterranean diet or Dietary Approach to Stop Hypertension (DASH) diet should be recommended.

\section{Alcohol consumption}

Alcohol consumption is another established risk factor for CA rupture. It may affect aneurysm risk through inflammation-mediated mechanisms but also by increasing blood pressure [33, 35]. In a metaanalysis of 14 observational studies performed by Yao et al. [53] heavy alcohol consumption ( $>30 \mathrm{~g}$ per day) was associated with an increased risk of SAH (RR 1.78; 95\% CI 1.46-2.17) compared to no alcohol intake. An increase in alcohol intake by $10 \mathrm{~g}$ per day was observed to increase the risk of SAH by $12.1 \%$. Can et al. [8] shown that current alcohol use was related to ruptured cerebral aneurysm status in comparison with no alcohol consumption (OR 1.36; 95\% CI 1.17-1.58). 
No relationship was observed with reference to former alcohol use (OR 1.23; 95\% CI 0.92-1.63).

In the light of the recent research, beneficial level of alcohol intake does not exist in the general population [15]. It is considered that recommended levels of its consumption presented in most of the current guidelines should be lowered [51]. Individuals at high risk of CA formation, as well as subjects with unruptured aneurysms, should particularly benefit from alcohol limitation.

\section{Dietary recommendations in clinical practice}

Dietary recommendations in prevention of CA formation and rupture should focus on the adequate intake of anti-inflammatory agents, vitamin $\mathrm{B}_{6}$, vitamin $\mathrm{B}_{12}$ and folate, avoidance of alcohol and maintenance of normal blood pressure. Dietary nutrients with antiinflammatory properties include mainly antioxidant vitamins (vitamin $\mathrm{C}$, vitamin $\mathrm{E}$ and carotenoids), flavonoids and n-3 fatty acids, which reduce the proinflammatory eicosanoid production [40]. Dietary sources of these nutrients are fruit and vegetables, herbs and spices, tea, nuts and seeds and fatty fish. A rich source of folate are leafy greens, nuts and pulses, vitamin $\mathrm{B}_{6}-$ grains, poultry and fish, while vitamin $\mathrm{B}_{12}$ - animal products [23].

Shine et al. [39] performed a case-control study to determine whether specific dietary habits might be associated with the risk of subarachnoid hemorrhage in Australasian population. Authors shown that consumption of fat or skin on meat was related to higher risk of SAH (p for trend 0.04), while inverse relationship was observed with reference to skim or reduced-fat milk ( $\mathrm{p}$ for trend 0.01 ) and fruit consumption ( $\mathrm{p}$ for trend 0.04). Adjusted OR was highest in group of individuals who consumed fat or skin on meat more than 4 times a week compared with those with no fat or skin on meat intake (OR 1.70; 95\% CI 1.09-2.66). Moreover, frequent adding salt to dishes was associated with higher risk of SAH in individuals with history of hypertension, both taking anti-hypertensive drugs (OR 2.58; 95\% CI 1.295.13) and those without pharmacological treatment of hypertension (OR 2.88; 95\% CI 1.46-5.70). According to authors, $15 \%(5-24 \%)$ of SAH cases were attributed to eating fruit less than once a week [38].

Due to the synergistic effect of various dietary components on health, it appears that nutritional recommendations in CA prevention should be based on the overall healthy dietary pattern, not only on single product or nutrient intake. According to existing evidence on the association between diet-related factors and aneurysm risk, specific dietary models which might be recommended for patients at high risk for developing the disease are Mediterranean (modified by eliminating wine intake) or DASH diets. Both of them are used in the nutritional therapy of hypertension and due to high consumption of vegetables and fruits they provide significant amounts of antioxidants and folate $[41,45]$. High anti-inflammatory potential is attributed especially to Mediterranean diet because of its characteristic composition of herbs, spices and fats [42].

\section{CONCLUSIONS}

Risk factors for cerebral aneurysm formation and rupture which may be altered by nutritional modifications include: inadequate intake of dietary antioxidants, hyperhomocysteinemia, hypertension and alcohol intake. Individuals at high risk of CA formation and rupture should consume adequate amounts of vegetables, fruits, grains, nuts and fish, which are good sources of antioxidant vitamins (vitamin $\mathrm{C}$, vitamin $\mathrm{E}$ and carotenoids), $\mathrm{B}$ vitamins (vitamin $\mathrm{B}_{6}$, vitamin $\mathrm{B}_{12}$ and folate), flavonoids and n-3 fatty acids. Alcohol limitation, regular blood pressure control and avoidance of caffeine, a risk factor for incidental high blood pressure, should be advised. Mediterranean and DASH diets appear to meet above-mentioned requirements, they may be thus recommended for prevention of cerebral aneurysm formation and rupture.

\section{REFERENCES}

1. Aoki T., Kataoka H., Ishibashi R., Nozaki K., Egashira $K$., Hashimoto N.: Impact of monocyte chemoattractant protein-1 deficiency on cerebral aneurysm formation. Stroke 2009;40(3):942-951 doi:10.1161/ STROKEAHA.108.532556.

2. Aoki T., Kataoka H., Morimoto M., Nozaki K., Hashimoto N.: Macrophage-derived matrix metalloproteinase-2 and -9 promote the progression of cerebral aneurysms in rats. Stroke 2007;38(1):162-169 doi:10.1161/01. STR.0000252129.18605.c8.

3. Aoki T., Nishimura M., Kataoka H., Ishibashi R., Nozaki K., Hashimoto N.: Reactive oxygen species modulate growth of cerebral aneurysms: a study using the free radical scavenger edaravone and p47phox(-/-) mice. Lab Invest 2009;89(7):730-741 doi:10.1038/ labinvest.2009.36.

4. Aoki T., Nishimura M., Matsuoka T., Yamamoto K., Furuyashiki T., Kataoka H., Kitaoka S., Ishibashi R., Ishibazawa A., Miyamoto S., Morishita R., Ando J., Hashimoto N., Nozaki K., Narumiya S.: PGE(2) -EP(2) signalling in endothelium is activated by haemodynamic stress and induces cerebral aneurysm through an amplifying loop via NF- $\kappa B$. Br J Pharmacol 2011;163(6):1237-1249 doi:10.1111/j.14765381.2011.01358.x.

5. Aune D., Keum N., Giovannucci E., Fadnes L.T., Boffetta P., Greenwood D.C., Tonstad S., Vatten L.J., Riboli E., Norat T: Dietary intake and blood concentrations of antioxidants and the risk of cardiovascular disease, total 
cancer, and all-cause mortality: a systematic review and dose-response meta-analysis of prospective studies. Am J Clin Nutr. 2018;108(5):1069-1091 doi: 10.1093/ajcn/ nqy097.

6. Bo L.J., Miao Z., Wang Z.F., Zhang K.Z., Gao Z.: A study on effect of curcumin on anticerebral aneurysm in the male albino rats. Brain Behav 2017;7(9):e00729 doi: $10.1002 / \mathrm{brb3} .729$.

7. Brown R.D. Jr., Huston J., Hornung R., Foroud T., Kallmes D.F., Kleindorfer D., Meissner I., Woo D., Sauerbeck L., Broderick J.: Screening for brain aneurysm in the Familial Intracranial Aneurysm study: frequency and predictors of lesion detection. J Neurosurg 2008;108(6):1132-1138 doi:10.3171/ JNS/2008/108/6/1132.

8. Can A., Castro V.M., Ozdemir Y.H., Dagen S., Dligach D., Finan S., Yu S., Gainer V., Shadick N.A., Savova G., Murphy S., Cai T., Weiss S.T., Du R.: Alcohol consumption and aneurysmal subarachnoid hemorrhage. Transl Stroke Res 2018;9(1):13-19 doi:10.1007/s12975-017-0557-z.

9. Cassidy A., O’Reilly É.J., Kay C., Sampson L., Franz M., Forman J.P., Curhan G., Rimm E.B.: Habitual intake of flavonoid subclasses and incident hypertension in adults. Am J Clin Nutr. 2010;93(2):338-347 doi: 10.3945/ajcn.110.006783.

10. Chen Q.W., Edvinsson L., Xu C.B.: Cigarette smoke extract promotes human vascular smooth muscle cell proliferation and survival through ERK1/2- and NF-אB-dependent pathways. ScientificWorldJournal 2010;10:2139-2156 doi:10.1100/tsw.2010.201.

11. Cianfoni A., Pravatà E., De Blasi R., Tschuor C.S., Bonaldi $G$.: Clinical presentation of cerebral aneurysms. Eur J Radiol 2013;82(10):1618-1622 doi:10.1016/j. ejrad.2012.11.019.

12. Colarusso L., Serafini M., Lagerros Y.T., Nyren O., La Vecchia C., Rossi M., Ye W., Tavani A., Adami H.O., Grotta A., Bellocco R.: Dietary antioxidant capacity and risk for stroke in a prospective cohort study of Swedish men and women. Nutrition 2017;33:234-239 doi:10.1016/j.nut.2016.07.009.

13. Etminan N., Buchholz B.A., Dreier R., Bruckner P., Torner J.C., Steiger H.J., Hänggi D., Macdonald, R.L.: Cerebral aneurysms: formation, progression, and developmental chronology. Trans stroke res 2013;5(2):167-173 doi: 10.1007/s12975-013-0294-x.

14. FrösenJ., Piippo A., PaetauA., KangasniemiM., Niemelä M., Hernesniemi J., Jääskeläinen J.: Remodeling of saccular cerebral artery aneurysm wall is associated with rupture: histological analysis of 24 unruptured and 42 ruptured cases. Stroke 2004;35(10):2287-2293 doi:10.1161/01.STR.0000140636.30204.da.

15. GBD 2016 Alcohol Collaborators.: Alcohol use and burden for 195 countries and territories, 1990-2016: a systematic analysis for the Global Burden of Disease Study 2016. Lancet 2018;392(10152):1015-1035 doi:10.1016/S0140-6736(18)31310-2.

16. Gopal K., Nagarajan P., Raj T.A., Jahan P., Ganapathy H.S., Mahesh Kumar M.J.: Effect of dietary $\beta$ carotene on cerebral aneurysm and subarachnoid haemorrhage in the brain apo E-/- mice. J Thromb Thrombolysis 2011;32(3):343-355 doi:10.1007/s11239-011-0620-7.

17. Hasan D.M., Mahaney K.B., Brown R.D., Meissner I., Piepgras D.G., Huston J., Capuano A.W., Torner J.C., International Study of Unruptured Intracranial Aneurysms Investigators.: Aspirin as a promising agent for decreasing incidence of cerebral aneurysm rupture. Stroke. 2011;42(11):3156-3162 doi:10.1161/ STROKEAHA.111.619411.

18. Inci S., Spetzler R.F.: Intracranial aneurysms and arterial hypertension: a review and hypothesis. Surg Neurol 2000;53(6):530-542.

19. Isaksen J., Egge A., Waterloo K., Romner B., Ingebrigtsen T: Risk factors for aneurysmal subarachnoid haemorrhage: the Tromsø study. J Neurol Neurosurg Psychiatry 2002;73(2):185-187 doi: 10.1136/jnnp.73.2.185.

20. Kim Y., Je Y.: Flavonoid intake and mortality from cardiovascular disease and all causes: A meta-analysis of prospective cohort studies. Clin Nutr ESPEN 2017;20:68-77 doi:10.1016/j.clnesp.2017.03.004.

21. Kleinloog R., de Mul N., Verweij B.H., Post J.A., Rinkel G.J.E., Ruigrok Y.M.: Risk factors for intracranial aneurysm rupture: a systematic review. Neurosurgery 2018;82(4):431-440 doi:10.1093/neuros/nyx238.

22. Korai M., Kitazato K.T., Tada Y., Miyamoto T., Shimada K., Matsushita N., Kanematsu Y., Satomi J., Hashimoto T., Nagahiro S.: Hyperhomocysteinemia induced by excessive methionine intake promotes rupture of cerebral aneurysms in ovariectomized rats. J Neuroinflammation 2016;13(1):165 doi:10.1186/ s12974-016-0634-3.

23. Lutsey P.L., Steffen L.M., Feldman H.A., Hoelscher D.H., Webber L.S., Luepker R.V., Lytle L.A., Zive M., Osganian S.K.: Serum homocysteine is related to food intake in adolescents: the Child and Adolescent Trial for Cardiovascular Health. Am J Clin Nutr 2006;83(6):1380-1386 doi: 10.1093/ajen/83.6.1380.

24. Marzatico F., Gaetani P., Tartara F., Bertorelli L., Feletti F., Adinolfi D., Tancioni F., Rodriguez y Baena $R$ : Antioxidant status and alphal-antiproteinase activity in subarachnoid hemorrhage patients. Life Sci 1998;63(10):821-826.

25. Ohkuma H., Suzuki S., Fujita S., Nakamura W.: Role of a decreased expression of the local renin-angiotensin system in the etiology of cerebral aneurysms. Circulation 2003;108(7):785-787 doi:10.1161/01 CIR.0000087339.31094.3C.

26. Okamoto K., Horisawa R.: Dietary antioxidant intake and risk of an aneurysmal rupture subarachnoid hemorrhage in Japan. Eur J Clin Nutr 2007;61(9):11401142 doi:10.1038/sj.ejen.1602669

27. Okamoto K., Horisawa R.: Soy products and risk of an aneurysmal rupture subarachnoid hemorrhage in Japan. Eur J Cardiovasc Prev Rehabil. 2006;13(2):284-287 doi:10.1097/01.hjr.0000194419.24261.5c

28. Okamoto K., Horisawa R.: The joint effect of oxidative stress and antioxidants on the risk of an aneurysmal rupture subarachnoid hemorrhage: a case-control study in Japan. Ann Epidemiol 2007;17(5):359-363 doi:10.1016/j.annepidem.2006.12.001. 
29. Okamoto $K$.: Habitual green tea consumption and risk of an aneurysmal rupture subarachnoid hemorrhage: a case-control study in Nagoya, Japan. Eur J Epidemiol 2006;21(5):367-371 doi: 10.1007/s10654-006-9000-6.

30. Parodi F.E., Mao D., Ennis T.L., Pagano M.B., Thompson R.W.: Oral administration of diferuloylmethane (curcumin) suppresses proinflammatory cytokines and destructive connective tissue remodeling in experimental abdominal aortic aneurysms. Ann Vasc Surg 2006;20(3):360-368 doi:10.1007/s10016-0069054-7.

31. Peng H.Y., Man C.F., Xu J., Fan Y.: Elevated homocysteine levels and risk of cardiovascular and allcause mortality: a meta-analysis of prospective studies. J Zhejiang Univ Sci B 2015;16(1):78-86 doi: 10.1631/ jzus.B1400183.

32. Puchau B., Zulet M.A., de Echávarri A.G., Hermsdorff H.H., Martínez J.A.: Dietary total antioxidant capacity: a novel indicator of diet quality in healthy young adults. J Am Coll Nutr 2009;28(6):648-656.

33. Qin L., Crews F.T.: NADPH oxidase and reactive oxygen species contribute to alcohol-induced microglial activation and neurodegeneration. J Neuroinflammation 2012;9:5 doi:10.1186/1742-2094-9-5.

34. Rautiainen S., Larsson S., Virtamo J., Wolk A.: Total antioxidant capacity of diet and risk of stroke: a population-based prospective cohort of women. Stroke 2012;43(2):335-340 doi:10.1161/ STROKEAHA.111.635557.

35. Reddy V.D., Padmavathi P., Kavitha G., Saradamma B., Varadacharyulu N.: Alcohol-induced oxidative/ nitrosative stress alters brain mitochondrial membrane properties. Mol Cell Biochem 2013;375(1-2):39-47 doi:10.1007/s11010-012-1526-1.

36. Ren J.R., Ren S.H., Ning B., Wu J., Cao Y., Ding X.M., Zhen Z.G., Hao X.D., Wang S.: Hyperhomocysteinemia as a risk factor for saccular intracranial aneurysm: a cohort study in a Chinese Han population. J Stroke Cerebrovasc Dis 2017;26(12):2720-2726 doi:10.1016/j. jstrokecerebrovasdis.2017.01.001.

37. Rosi J., Morais B.A., Pecorino L.S., Oliveira A.R., Solla D.J.F., Teixeira M.J., Figueiredo E.G.: Hyperhomocysteinemia as a risk factor for intracranial aneurysms: a case-control study. World Neurosurg 2018;119:e272-e275 doi:10.1016/j.wneu.2018.07.132.

38. Shiue I., Arima H., Hankey G.J., Anderson C.S., ACROSS Group:: Modifiable lifestyle behaviours account for most cases of subarachnoid haemorrhage: a populationbased case-control study in Australasia. J Neurol Sci 2012;313(1-2):92-94 doi:10.1016/j.jns.2011.09.017.

39. Shiue I., Arima H., Hankey G.J., Anderson C.S., ACROSS Group.: Modifiable lifestyle behaviours account for most cases of subarachnoid haemorrhage: A population-based case-control study in Australasia. J Neurol Sci 2012;313(1):92-94 doi:10.1016/j. jns.2011.09.017.

40. Shivappa N., Steck S.E., Hurley T.G., Hussey J.R., Hébert J.R.: Designing and developing a literaturederived, population-based dietary inflammatory index. Public Health Nutr 2014;17(8):1689-1696 doi:10.1017/ S1368980013002115.
41. Siervo M., Lara J., Chowdhury S., Ashor A., Oggioni C., Mathers J.C.: Effects of the Dietary Approach to Stop Hypertension (DASH) diet on cardiovascular risk factors: a systematic review and meta-analysis. Br J Nutr 2015;113(1):1-15 doi:10.1017/S0007114514003341.

42. Steck S.E., Shivappa N., Tabung F.K., Harmon B.E., Wirth M.D., Hurley T.G., Hebert J.R.: The Dietary Inflammatory Index: a new tool for assessing diet quality based on inflammatory potential. The Digest 2014;49(3):2-9.

43. Tada Y., Wada K., Shimada K., Makino H., Liang E.I., Murakami S., Kudo M., Kitazato K.T., Nagahiro S., Hashimoto T: Roles of hypertension in the rupture of intracranial aneurysms. Stroke 2013;45(2):579-586 doi: 10.1161/STROKEAHA.113.003072.

44. Thompson B.G., Brown R.D. Jr., Amin-Hanjani S., Broderick J.P., Cockroft K.M., Connolly E.S. Jr., Duckwiler G.R., Harris C.C., Howard V.J., Johnston S.C., Meyers P.M., Molyneux A., Ogilvy C.S., Ringer A.J., Torner J., American Heart Association Stroke Council, Council on Cardiovascular and Stroke Nursing, and Council on Epidemiology and Prevention, American Heart Association, American Stroke Association:: Guidelines for the management of patients with unruptured intracranial aneurysms: a guideline for healthcare professionals from the American Heart Association/American Stroke Association. Stroke 2015;46(8):2368-2400 doi:10.1161/ STR.0000000000000070.

45. Toledo E., Hu F.B., Estruch R., Buil-Cosiales P., Corella D., Salas-Salvadó J., Covas M.I., Arós F., Gómez-Gracia E., Fiol M., Lapetra J., Serra-Majem L., Pinto X., Lamuela-Raventós R.M., Saez G., Bulló M., Ruiz-Gutiérrez V., Ros E., Sorli J.V., MartinezGonzalez M.A.: Effect of the Mediterranean diet on blood pressure in the PREDIMED trial: results from a randomized controlled trial. BMC Med 2013;11:207 doi:10.1186/1741-7015-11-207.

46. van der Voet M., Olson J.M., Kuivaniemi H., Dudek D.M., Skunca M., Ronkainen A., Niemelä M., Jääskeläinen J., Hernesniemi J., Helin K., Leinonen E., Biswas M., Tromp G.: Intracranial aneurysms in Finnish families: confirmation of linkage and refinement of the interval to chromosome 19q13.3. Am J Hum Genet 2004;74(3):564-571 doi:10.1086/382285.

47. Vlak M.H., Algra A., Brandenburg R., Rinkel G.J.: Prevalence of unruptured intracranial aneurysms, with emphasis on sex, age, comorbidity, country, and time period: a systematic review and meta-analysis. Lancet Neurol 2011;10(7):626-636 doi:10.1016/S14744422(11)70109-0.

48. Vlak M.H., Rinkel G.J., Greebe P., van der Bom J.G., Algra A.: Trigger factors and their attributable risk for rupture of intracranial aneurysms: a case-crossover study. Stroke 2011;42(7):1878-1882 doi:10.1161/ STROKEAHA.110.606558.

49. Wald D.S., Law M., Morris J.K.: Homocysteine and cardiovascular disease: evidence on causality from a meta-analysis. BMJ 2002;325(7374):1202 doi:10.1136/ bmj.325.7374.1202. 
50. Woo D., Khoury J., Haverbusch M.M., Sekar P., Flaherty M.L., Kleindorfer D.O., Kissela B.M., Moomaw C.J., Deka R., Broderick J.P.: Smoking and family history and risk of aneurysmal subarachnoid hemorrhage. Neurology 2009;72(1):69-72 doi:10.1212/01. wnl.0000338567.90260.46.

51. Wood A.M., Kaptoge S., Butterworth A.S., Willeit P., Warnakula S., Bolton T., Paige E., Paul D.S., Sweeting M., Burgess S., Bell S., Astle W., Stevens D., Koulman A., Selmer R.M., Verschuren W.M.M., Sato S., Njølstad I., Woodward M., Salomaa V., Nordestgaard B.G., Yeap B.B., Fletcher A., Melander O., Kuller L.H., Balkau B., Marmot M., Koenig W., Casiglia E., Cooper C., Arndt V., Franco O.H., Wennberg P., Gallacher J., de la Cámara A.G., Völzke H., Dahm C.C., Dale C.E., Bergmann M.M., Crespo C.J., van der Schouw Y.T., Kaaks R., Simons L.A., Lagiou P., Schoufour J.D., Boer J.M.A., Key T.J., Rodriguez B., Moreno-Iribas C., Davidson K.W., Taylor J.O., Sacerdote C., Wallace R.B., Quiros J.R., Tumino R., Blazer D.G., Linneberg A., Daimon M., Panico S., Howard B., Skeie G., Strandberg T., Weiderpass E., Nietert P.J., Psaty B.M., Kromhout D., Salamanca-Fernandez E., Kiechl S., Krumholz H.M., Grioni S., Palli D., Huerta J.M., Price J., Sundström J., Arriola L., Arima H., Travis R.C., Panagiotakos D.B., Karakatsani A., Trichopoulou A., Kühn T., Grobbee D.E., Barrett-Connor E., van Schoor N., Boeing H., Overvad K., Kauhanen J., Wareham N., Langenberg C., Forouhi N., Wennberg M., Després J.P., Cushman M., Cooper J.A., Rodriguez C.J., Sakurai M., Shaw J.E., Knuiman M., Voortman T., Meisinger C., Tjønneland A., Brenner H., Palmieri L., Dallongeville
J., Brunner E.J., Assmann G., Trevisan M., Gillum R.F., Ford I., Sattar N., Lazo M., Thompson S.G., Ferrari P., Leon D.A., Smith G.D., Peto R., Jackson R., Banks E., Di Angelantonio E., Danesh J., Emerging Risk Factors Collaboration/EPIC-CVD/UK Biobank Alcohol Study Group.: Risk thresholds for alcohol consumption: combined analysis of individual-participant data for 599912 current drinkers in 83 prospective studies. Lancet 2018;391(10129):1513-1523 doi:10.1016/ S0140-6736(18)30134-X.

52. Xu Y., Tian Y., Wei H.J., Dong J.F., Zhang J.N.: Methionine diet-induced hyperhomocysteinemia accelerates cerebral aneurysm formation in rats. Neurosci Lett 2011;494(2):139-144 doi:10.1016/j. neulet.2011.02.076.

53. Yao X., Zhang K., Bian J., Chen G.: Alcohol consumption and risk of subarachnoid hemorrhage: A meta-analysis of 14 observational studies. Biomed Rep 2016;5(4):428-436 doi: 10.3892/br.2016.743.

54. Zhou Z., Liang Y., Qu H, Zhao M., Guo F., Zhao C., Teng $W$.: Plasma homocysteine concentrations and risk of intracerebral hemorrhage: a systematic review and meta-analysis. Sci Rep 2018;8(1):2568 doi:10.1038/ s41598-018-21019-3.

55. Ziemba-Davis M., Bohnstedt B.N., Payner T.D., Leipzig T.J., Palmer E., Cohen-Gadol A.A.: Incidence, epidemiology, and treatment of aneurysmal subarachnoid hemorrhage in 12 midwest communities. J Stroke Cerebrovasc Dis 2014;23(5):1073-1082 doi:10.1016/j. jstrokecerebrovasdis.2013.09.010.

Received: 15.01 .2019

Accepted: 20.03.2019

This article is available in Open Access model and licensed under a Creative Commons Attribution-Non Commercial 3.0.Poland License (CC-BY-NC) available at: http://creativecommons.org/licenses/by-nc/3.0/pl/deed.en 